Al-Bidayah : jurnal pendidikan dasar Islam

Volume 13, Number 1, June 2021

ISSN: 2549-3388 (online)

Available online at https://jurnal.albidayah.id

Submitted: September 7, 2019, Accepted: June 29, 2021

\title{
FOSTERING THE ALPHA GENERATION: A CHARACTER EDUCATION BASED ON JAVANESE UNGGAH UNGGUH (ETIQUETTE) CULTURE IN MADRASAH IBTIDAIYAH
}

\author{
Aprilian Ria Adisti', Muhamad Rozikan² \\ Institut Agama Islam Negeri Salatiga, Indonesia ${ }^{1,2}$ \\ E-mail: aprilian@iainsalatiga.ac.id ${ }^{1}$, muhamadrozikan@iainsalatiga.ac.id ${ }^{2}$
}

DOI: 10.14421/al-bidayah.v13i1.256

\begin{abstract}
This paper portrays the implementation of character education based on Javanese unggah-ungguh (etiquette) in Madrasah Ibtidaiyah Karanganyar, using 24 students from $5^{\text {th }}$-grade who were mentioned as the alpha generation in 2020. Generally, this generation refers to children born after 2010 in this digital era. The unggah-ungguh is one of the Indonesian ancestral heritages that must be preserved, as though it may originate from Java, it strongly represents the culture of the country's society. Six (6) characters of Javanese unggah-ungguh were used in this research as indicators, which are tata krama (manners), lembah manah (relent), andhap asor (humility), tepa slira (tolerance), grapyak (friendliness), and ewuh-pekewuh (reluctance). This study was descriptive qualitative research that focused on observing the realization of character education based on this culture, using observation, interview, survey, and documentation as the data collection instruments. As reviewed from the affective theory of Krathwohl Taxonomy, the education character based on Javanese unggah-ungguh has influenced three-component domains of affective attitudes, which are in the level of receiving or attending, responding, and valuing. Lastly, the result showed that implementing character education based on this culture has truly shaped a better personality for students in Madrasah Ibtidaiyah Karanganyar as the alpha generation.
\end{abstract}

Keywords: alpha generation; character education; javanese unggah-ungguh; madrasah ibtidaiyah

\section{INTRODUCTION}

The 4.0 industrial revolution era is marked by sophisticated technology development. ${ }^{1}$ Therefore, building a strong character, especially for the young Indonesian generations, to protect themselves from the penetration of foreign cultural influences is necessary. A character education ${ }^{2}$ plays a crucial role in strengthening national identity, and the Indonesian government made a policy program for this purpose for 2010-2025. This national policy aims to realize the ideals of the Indonesian people based on four national pillars, namely Pancasila, UUD 1945, NKRI, and Bhineka Tunggal Ika.

${ }^{1}$ Aida Aryani Shahroom and Norhayati Hussin, "Industrial Revolution 4.0 and Education," International Journal of Academic Research in Business and Social Sciences, 2018, https://doi.org/10.6007/ijarbss/v8-i9/4593.

${ }^{2}$ Andrew Peterson, "Character Education, the Individual and the Political," Journal of Moral Education, 2020, https://doi.org/10.1080/03057240.2019.1653270. 
With this policy, all the elements are expected to have the same goal in transforming character education. ${ }^{3}$

As a multicultural nation, ${ }^{4}$ Indonesia has diverse local wisdom based on society's cultural values. Character education can be formed through the inculcation of various values developed related to the wisdom of the community's local culture. ${ }^{5}$ One of the local cultures in Indonesia is the Javanese unggah-ungguh (etiquette), ${ }^{6}$ a character based on the wisdom of the local culture. It contains the values of the Javanese people's life structure, such as norms, beliefs, habits, conceptions, and symbols, that develop in society. One characteristic of the Javanese unggah-ungguh is reflected in an attitude of tolerance, affection, cooperation, humanity, the value of respect, and gratitude. ${ }^{7}$

Meanwhile, Milan Halgren stated that the alpha generation refers to children born after $2010^{8}$, while Peter Karacsony mentioned that it might be children from the "Y" or "Z" generation. Hence, the alpha generation descended from and represented crossing the " $Z$ " generation with this digital era as the new era. ${ }^{9}$ They are familiar with accessing information technology, even while still in the womb, which is why caring for them has different challenges from previous generations. The effect of technology on the alpha generation also makes them more critical than other generations. These children are usually critical because of the ease of information obtained and will undoubtedly face more challenges, primarily due to the penetration of foreign cultures into their daily lives through technology. Therefore, strengthening their character through education is very

${ }^{3}$ Joko Ansari Setiawan et al., "The Role of Parents on the Character Education of Kindergarten Children Aged 5-6 Years in Bima," Universal Journal of Educational Research, 2020, https://doi.org/10.13189/ujer.2020.080307.

4 James A. Banks, "Multicultural Education," in International Encyclopedia of the Social \& Behavioral Sciences: Second Edition, 2015, https://doi.org/10.1016/B978-0-08-097086-8.92097-X.

${ }^{5}$ Mimien Henie Irawati Al Muhdhar et al., "Local Wisdom-Based Conservation Ethics Of Tabaru Traditional Community On Halmahera Island, Indonesia.," International Journal of Conservation Science 10, no. 3 (2019), http://ijcs.ro/public/IJCS-19-49_Almudhar.pdf.

${ }^{6}$ Aprilian Ria Adisti, "Internalization Of Javanese Unggah-Ungguh (Etiquette) Character In Modern Era Through Personality Course At English Education Department," AL-ISHLAH: Jurnal Pendidikan 10, no. 2 (December 30, 2018): 216-30, https://doi.org/10.35445/alishlah.v10i2.89.

${ }^{7}$ Eka Susylowati, "The Use of Javanese by Society of Keraton Surakarta Hadiningrat," Journal of English Teaching and Learning Issues, 2019, https://doi.org/10.21043/jetli.v2i1.5227.

${ }^{8}$ Milan Halgren et al., "The Generation and Propagation of the Human Alpha Rhythm," Proceedings of the National Academy of Sciences of the United States of America, 2019, https://doi.org/10.1073/pnas.1913092116.

${ }^{9}$ Peter Karácsony, Tilla Izsák, and László Vasa, “Attitudes of z Generation to Job Searching through Social Media," Economics and Sociology, 2020, https://doi.org/10.14254/2071-789X.2020/13$4 / 14$. 
necessary, and one way is through the internalization of character education based on the local wisdom ${ }^{10}$ of the Javanese unggah-ungguh culture.

According to the National Education System Law No.20 of 2003 article 1 point 1 , education is a conscious and planned effort to create an atmosphere of learning. It is also a process to ensure students actively develop their potential to have religious-spiritual strength, self-control, personality, intelligence, noble character, and the skills needed by them, society, the nation, and the country. These elements are essential parts of character education that must be applied in schools. Character education represents a relationship between knowledge, values, and skills necessary for success in life. Moreover, Balraj ${ }^{11}$ stated that character education refers to how people develop good characters and show personal qualities that the community wants. Character education is a genuine effort to help a person understand, care, and act based on ethical values. ${ }^{12}$ It can also be interpreted as a deliberate growing discipline and attempt to develop students' ethical behaviors at school and become an everyday opportunity. The crucial elements of character education that should be optimized for students are respect, truth, fairness, and responsibility. ${ }^{13}$

Local wisdom ${ }^{14}$ is an alternative source of life wisdom values containing wise ideas and behaviors that can be used as guidelines for daily activities. These activities may concern family relations, neighbors, and others who live in the vicinity, alongside media for building informal educational institutions such as schools. ${ }^{15}$ The role of local wisdom is critically changing and shaping global culture to become meaningful and follow the social and cultural life of the community. Hence, youths that are aware and adopt the values of local wisdom earlier will use it as an analysis in dissecting and

${ }^{10}$ Sukadari et al., "Local Socio-Cultural Wisdom as a Basis of Character Education in Primary Schools," International Journal of Innovation, Creativity and Change 7, no. 6 (2019): 298-311, https://www.ijicc.net/images/vol7iss6/7620_Sukadari_2019_E_R.pdf.

${ }^{11}$ Balraj Singh, "Character Education in the 21st Century," Journal of Social Studies (JSS), 2019, https://doi.org/10.21831/jss.v15i1.25226.

12 Robert E. McGrath et al., "What Does Character Education Mean to Character Education Experts? A Prototype Analysis of Expert Opinions," Journal of Moral Education, 2021, https://doi.org/10.1080/03057240.2020.1862073.

13 Agnieszka Bates, "Character Education and the 'Priority of Recognition,"” Cambridge Journal of Education, 2019, https://doi.org/10.1080/0305764X.2019.1590529.

${ }^{14}$ Sue E. Smith, Jon C. Mason, and Majella Bowden, "Local Wisdom in Regenerative Teacher Practices," Australian Journal of Teacher Education, 2020, https://doi.org/10.14221/ajte.2020v45n9.6.

15 Pieter Sahertian and Umiati Jawas, "Local Wisdom and Excellent Leadership: A Phenomenological Approach," Journal of Advanced Research in Dynamical and Control Systems, 2020, https://doi.org/10.5373/JARDCS/V12SP1/20201139. 
separating foreign cultures ${ }^{16}$. One of the local wisdom that can be used as character education is the introduction of Javanese unggah-ungguh.

Eleftherios L. Thalassinos mentioned two rules that determine the patterns of association and character of Javanese society, namely behaving to avoid causing conflict and respecting others according to their degree and position. ${ }^{17}$ In Javanese ethics, F.M. Suseno quotes Hildred Geertz by saying that respect is achieved through three feelings, namely wedi (fear), isin (shame), and sungkan (reluctance). Meanwhile, several characters are inherent in the Javanese society and philosophy of life ${ }^{18}$, including tata krama (manners), lembah manah (relent), andhap asor (humility), tepa slira (tolerance), grapyak (friendliness), and ewuh-pekewuh (reluctance). These six (6) characters are indicators of the Javanese unggah-ungguh examined in this research.

Some previous studies have discussed character education for the alpha generation, for instance, Thompson exposed the term alpha generation. Based on the national survey in 2017 held by Mark McCrindle, a demographics expert in Australia 2017, the alpha generation is the name that most respondents choose ${ }^{19}$. Also, Susan Fourtane showed that Google had anticipated this generation that tends to be more familiar with communication through visuals such as image and audio than a manual type of message in communication. ${ }^{20}$ Then, Scott Bennett et al. conducted ethnographic research on an alpha generation, showing that they are very creative because they adapt well to the digital era. Moreover, the alpha generation is predicted to face more opportunities and challenges. ${ }^{21}$

In addition, some research examined character education, such as Michael Nixon et al., who researched the role of the character in improving curricular and non-

\footnotetext{
16 Jozef Bremer, "Wittgenstein's Remarks Concerning the Accessibility of Foreign Cultures," Wittgenstein-Studien, 2017, https://doi.org/10.1515/witt-2017-007.

${ }^{17}$ Tulus Suryanto, "Cultural Ethics And Consequences In Whistle-Blowing Among Professional Accountants: An Empirical Analysis," Journal of Applied Economic Sciences 12, no. 6 (2017), http://cesmaa.org/Docs/JAES\%20Fall\%206(52)2017_online.pdf\#page=70.

${ }^{18}$ Istijabatul Aliyah, "The Roles of Traditional Markets as the Main Component of Javanese Culture Urban Space (Case Study: The City of Surakarta, Indonesia)," IAFOR Journal of Sustainability, Energy \& the Environment, 2016, https://doi.org/10.22492/ijsee.3.1.06.

19 Thompson Augusto dos Reis, "Study On The Alpha Generation And The Reflections Of Its Behavior In The Organizational Environment," Quest Journals J Res Humanit Soc Sci 6 (2018): 9-19, http://www.questjournals.org/jrhss/papers/vol6-issue1/C610919.pdf.

${ }^{20}$ Susan Fourtané, "Generation Alpha: The Children of the Millennial," Interesting Engineering, December 18, 2018, https://interestingengineering.com/generation-alpha-the-children-of-the-millennial.

${ }^{21}$ Scott Bennett et al., "Alpha Generation in Portfolio Management: Long-Run Australian Equity Fund Evidence,” Australian Journal of Management, 2016, https://doi.org/10.1177/0312896214539815.
} 
curricular performance in 24 schools $^{22}$. Benninga et al. also showed the relationship between the implementation of character education and students' academic achievement. It concluded that schools that implement serious and well-designed character education tend to score higher academic performances for their students. Furthermore, Shiri Lavy proposed five important character values that prioritize strengthening the character education movement, namely religious, nationalist, self-help, mutual, and integrity ${ }^{23}$. Research on Javanese unggah-ungguh has also been conducted, including Handayani, which revealed the role in interacting with others. Other studies that discussed this culture include communication ethics in Javanese culture by Purwadi, ${ }^{24}$ a study by Supartinah ${ }^{25}$ about the role of unggah-ungguh in instilling politeness, and a study by Safari and Denis about interactive multimedia development of Javanese unggah-ungguh. ${ }^{26}$

Based on the entire research above, more character education is still needed for children ${ }^{27}$. One way to provide this education is through local cultural wisdom, such as the Javanese unggah-ungguh. ${ }^{28}$ The reason is that children living in the alpha generation ${ }^{29}$ are very close to technological advances greatly influenced by foreign cultures. This fact is due to the increasingly eroded unggah-ungguh replaced by western characters that continue to penetrate millennial generations in this era of globalization. Therefore, this research has novelty aspects, such as its implementation on a Madrasah Ibtidaiyah, representing primary education in Islamic-based schools. In addition, character education

${ }^{22}$ Michael Nixon, Steve DiPaola, and Ulysses Bernardet, "An Eye Gaze Model for Controlling the Display of Social Status in Believable Virtual Humans," in IEEE Conference on Computatonal Intelligence and Games, CIG, 2018, https://doi.org/10.1109/CIG.2018.8490373.

${ }^{23}$ Shiri Lavy and Maya Benish-Weisman, "Character Strengths as 'Values in Action': Linking Character Strengths With Values Theory - An Exploratory Study of the Case of Gratitude and SelfTranscendence," Frontiers in Psychology, 2021, https://doi.org/10.3389/fpsyg.2021.576189.

${ }^{24}$ Purwadi, "Keselarasan Antara Nilai Islam Dan Budaya Jawa Menurut Mangkunegara IV,” Ibda' Jurnal Kebudayaan Islam 8, no. 2 (2010): 1-19, https://123dok.com/document/y49g06vz-keselarasanantara-nilai-islam-dan-budaya-jawa.html.

${ }^{25}$ Supartinah Supartinah, Sekar Purbarini Kawuryan, and Woro Sri Hastuti, "Javanese Graded Reading Books For Elementary School Students," RETORIKA: Jurnal Bahasa, Sastra, Dan Pengajarannya 13, no. 1 (February 23, 2020): 56-65, https://doi.org/10.26858/retorika.v13i1.11321.

${ }^{26}$ Mohammad Safari and Dennis Ossy January, "The Development of Virtual Javanese Gamelan to Improve Gamelan Learning Achievement," MUDARRISA: Jurnal Kajian Pendidikan Islam, 2019, https://doi.org/10.18326/mdr.v10i2.222-244.

${ }^{27}$ Jean Paul Fischer, "Character Reversal in Children: The Prominent Role of Writing Direction," Reading and Writing, 2017, https://doi.org/10.1007/s11145-016-9688-y.

${ }^{28}$ Ika Nurani Dewi, Sri Poedjiastoeti, and Binar Kurnia Prahani, "ELSII Learning Model Based Local Wisdom To Improve Students' Problem Solving Skills And Scientific Communication," International Journal of Education and Research 5, no. 1 (2017): 107-18, http://br.ijern.com/journal/2017/January-2017/09.pdf.

29 Ádám Nagy and Attila Kölcsey, "Generation Alpha: Marketing or Science," Acta Technologica Dubnicae, 2017, https://doi.org/10.1515/atd-2017-0007. 
is based on the local wisdom of Javanese culture ${ }^{30}$, and the results of this study enrich the implementation and application at the primary education level. For this reason, achieving character education based on local cultural wisdom is an urgent matter. ${ }^{31}$

Shaping the Javanese unggah-ungguh characters in this research will be examined from The Krathwohl Taxonomy measurement ${ }^{32}$ used when there are scientific attitudes or affective components. According to Krathwohl in Leslie, ${ }^{33}$ there are five levels of the affective domain, namely Receiving or attending, Responding, Valuing, Organization, and Characterization.

Nowadays, character education based on local culture is rarely found, and only a few schools in Java still adhere to the unggah-ungguh (etiquette) culture as the basis for character education. Therefore, research that can promote character education based on local culture is expected to be a role model for other schools.

Systematically, figure 1 shows the scheme of the background of this research.

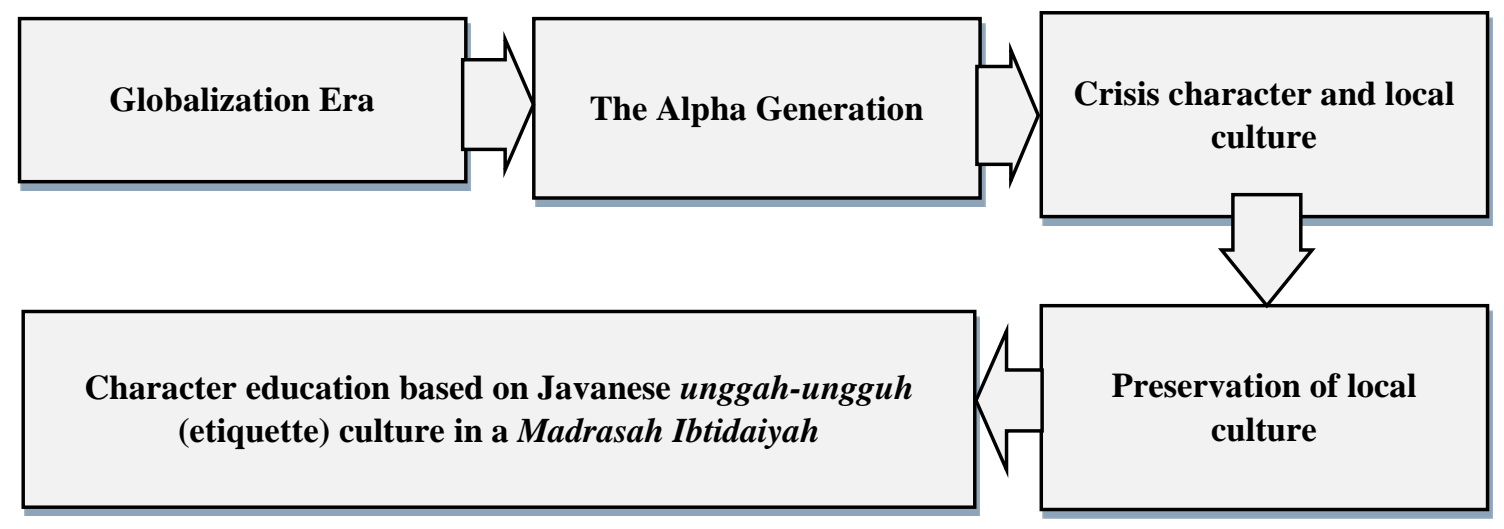

Figure 1

Background of Study

Children born since 2010 are referred to as the alpha generation. This generation is very vulnerable to local character and culture crises because their lives have been very

${ }^{30}$ Sulistiyono Susilo and Ibnu Syato, "Common Identity Framework of Cultural Knowledge and Practices of Javanese Islam," Indonesian Journal of Islam and Muslim Societies, 2016, https://doi.org/10.18326/ijims.v6i2.161-184.

${ }^{31}$ Nic M. Weststrate, Michel Ferrari, and Monika Ardelt, "The Many Faces of Wisdom: An Investigation of Cultural-Historical Wisdom Exemplars Reveals Practical, Philosophical, and Benevolent Prototypes," Personality and Social Psychology Bulletin, 2016, https://doi.org/10.1177/0146167216638075.

32 David R. Krathwohl, “A Revision of Bloom's Taxonomy: An Overview,” Theory Into Practice 41, no. 4 (November 1, 2002): 212-18, https://doi.org/10.1207/s15430421tip4104_2.

33 Leslie Owen Wilson, "Bloom's Taxonomy Revised," The Second Principle (blog), 2017, https://thesecondprinciple.com/essential-teaching-skills/blooms-taxonomy-revised/. 
close to foreign culture and technology since childhood. Therefore, to introduce and preserve local culture, it must be applied through character education to members of this generation, especially in Madrasah Ibtidaiyah. This study portrays the implementation of character education based on Javanese unggah-ungguh (etiquette) culture in a Madrasah Ibtidaiyah. In addition, it describes and analyzes the findings through Krathwohl's taxonomy to find out what level the Javanese unggah-ungguh (etiquette) culture education has been applied.

\section{RESEARCH METHODS}

This research used a descriptive qualitative method $^{34}$ to describe learning design implementation based on Javanese unggah-ungguh (etiquette) culture. The study was conducted in one of the Madrasah Ibtidaiyah Karanganyar in 2020. This school was chosen based on preliminary research conducted through a survey to determine which schools implemented character education based on unggah-ungguh. The subjects of this study were twenty-four students in $5^{\text {th }}$ grade, two teachers, and ten parents. Although character education at this school was implemented since the $1^{\text {st }}$ grade, the research focused on only the $5^{\text {th }}$-grade to limit the study based on some considerations recommended by the headmaster. Subsequently, the instruments used in this research were observation ${ }^{35}$ interview, ${ }^{36}$ survey, ${ }^{37}$ and documentation ${ }^{38}$. The observation was performed to describe the learning activity in character education. During this section, the students' and teachers' interactions were focused on, noted, and documented. At the same time, the survey and interview were used to get spoken information to strengthen the research result. Figure 1 shows a scheme of the steps of the research are stated systematically. ${ }^{39}$

\footnotetext{
${ }^{34}$ Sverre Varvin, “"The Essay Method' a Qualitative Method for Studying Therapeutic Dialogues,” Scandinavian Psychoanalytic Review, 2019, https://doi.org/10.1080/01062301.2019.1692622.

${ }^{35}$ Margaret R. Roller, "A Quality Approach to Qualitative Content Analysis: Similarities and Differences Compared to Other Qualitative Methods," Forum Qualitative Sozialforschung, 2019, https://doi.org/10.17169/fqs-20.3.3385.

36 Sara L. Gill, "Qualitative Sampling Methods," Journal of Human Lactation, 2020, https://doi.org/10.1177/0890334420949218.

37 John Gerring, "Qualitative Methods," Annual Review of Political Science, 2017, https://doi.org/10.1146/annurev-polisci-092415-024158.

${ }^{38}$ Sai Balakrishnan and Ann Forsyth, "Qualitative Methods," in The Routledge Handbook of International Planning Education, 2019, https://doi.org/10.4324/9781315661063-13.

${ }^{39}$ Corrado Matta, "Qualitative Research Methods and Evidential Reasoning," Philosophy of the Social Sciences, 2019, https://doi.org/10.1177/0048393119862858.
} 


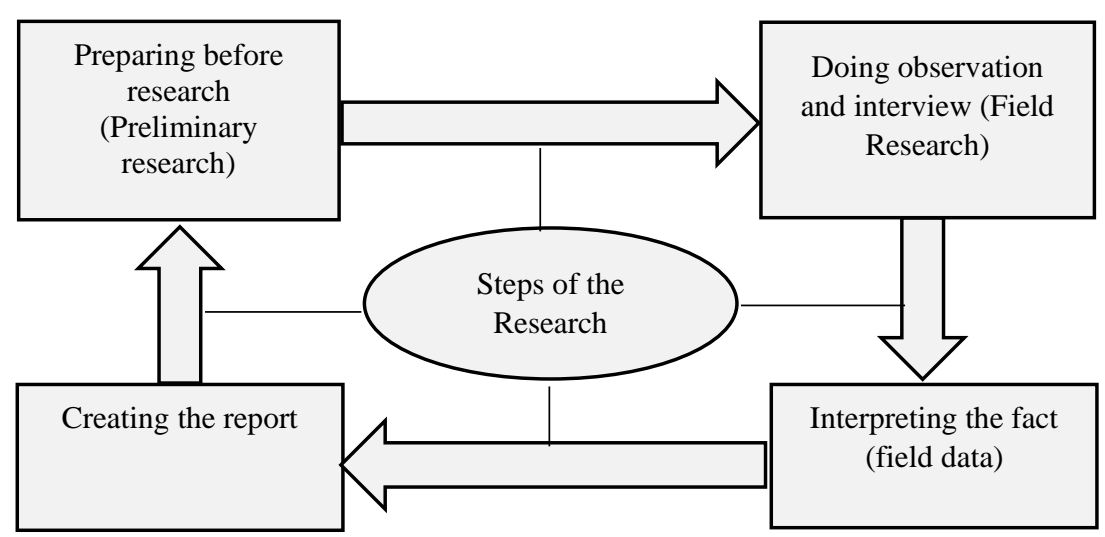

Figure 2

Steps of Conducting the Research

Preliminary research was the first step in conducting this study, which was performed to obtain pre-information taken from the observation, interview, and documentation. Information about the implementation of character education in Madrasah Ibtidaiyah was a vital object in this research. Here, some data were compiled to strengthen the next step of the research. Then, during the field research, the implementation of character education based on Javanese unggah-ungguh (etiquette) culture was observed. The headmaster, teachers, and parents were also actively interviewed about their perspectives to strengthen the observation. After the field research, data were collected and interpreted to obtain findings and conclusions. The credibility and validity of the research findings were increased through theoretical triangulation by combining theories, methods, or observers followed finally by creating the report after the findings were analyzed.

\section{RESULT AND DISCUSSION}

There are several characters inherent in Javanese unggah ungguh that become the indicators of character education. They are tata krama (manners), lembah manah (relent), andhap asor (humility), tepa slira (tolerance), grapyak (friendliness), and ewuhpekewuh (reluctance). Table 1 shows analyses according to The Krathwohl Taxonomy. 
Table 1

Analysis based on The Krathwohl Taxonomy

\begin{tabular}{|c|c|c|c|}
\hline No & $\begin{array}{l}\text { Character Formation of } \\
\text { Javanese unggah ungguh : }\end{array}$ & Example of Attitude & $\begin{array}{c}\text { Result } \\
\text { (already be } \\
\text { implemented) }\end{array}$ \\
\hline 1. & Tata krama & $\begin{array}{l}\text { speak politely with the teacher } \\
\text { and friends } \\
\text { showing polite gestures when } \\
\text { passing in front of an older } \\
\text { person } \\
\text { speak with polite intonation } \\
\text { and don't shout } \\
\text { sit politely } \\
\text { pay attention to how to behave } \\
\text { and talk, etc. }\end{array}$ & $\sqrt{ }$ \\
\hline 2. & Andhap asor & $\begin{array}{l}\text { not arrogant to his friends } \\
\text { value of respect } \\
\text { not calling his friend with a bad } \\
\text { name } \\
\text { not showing off } \\
\text { argues in ways that do not hurt } \\
\text { friends } \\
\text { wants to help friends, etc. }\end{array}$ & $\sqrt{ }$ \\
\hline 3. & Lembah manah & $\begin{array}{l}\text { shares with friends in certain } \\
\text { matters } \\
\text { shows affection } \\
\text { want to queue up } \\
\text { gives the friend a chance first } \\
\text { in certain matters, etc. }\end{array}$ & $\sqrt{ }$ \\
\hline 4. & Tepa slira & $\begin{array}{l}\text { have high empathy for friends } \\
\text { cares for friends } \\
\text { being understanding }\end{array}$ & $\sqrt{ }$ \\
\hline
\end{tabular}




\begin{tabular}{ll}
\hline & has humanity \\
& appreciates differences of \\
& opinion, etc. \\
\hline $5 . \quad$ Ewuh pekewuh & not seizing his friend's \\
& belongings \\
& have shame when guilty \\
& wants to apologize \\
& doesn't say rude things \\
& follows the teacher's advice, \\
& etc. \\
& always smiling at friends and \\
& talking pleasantly \\
& likes to help \\
Grapyak & friendly \\
& gives a good response when \\
& asked \\
& cheerful \\
& shows gratitude.
\end{tabular}

The key to building character education based on Javanese unggah-ungguh in this school is habituation. Students not only speak politely using the language but also show attitudes associated with the cultural personality, such tata krama (manners), lembah manah (relent), andhap asor (humility), tepa slira (tolerance), grapyak (friendliness), and ewuh-pekewuh (reluctance). As the role model, the teacher is gradually imitated by his students, and through this habit and character, education has successfully taught and instilled noble values of Javanese culture into the alpha generation in this school. This finding strengthened Elena Arbués ${ }^{40}$ that character education should be of Paraguay,” Estudios Sobre Educacion, 2019, https://doi.org/10.15581/004.37.159-178. 
implemented as a deliberate discipline or attempt habitually during growth to ensure students can develop their ethical behavior at school.

Furthermore, the data collection showed that the process of character education based on Javanese unggah-ungguh (etiquette) culture in $5^{\text {th }}$-grade students of MI Karanganyar was successful. The teacher applied the Javanese unggah-ungguh (etiquette) culture by inserting values in each story, so the students are more interested and imaginative while following the storyline. Also, they are expected to obtain the moral value contained in the story. During the teaching and learning process, the teacher always gives advice, reminds the students to instill good attitudes, behavior, and character. Hence, the students remember to implement the unggah-ungguh culture wherever they are and with whomever. According to Shirley Anne S. Paul, ${ }^{41}$ character education can be an everyday opportunity, meaning that practicing the unggah-ungguh daily at schools will positively impact and develop students' behaviors.

Two sections were applied in this school to shape the students' characters based on the Javanese unggah-ungguh. First, the implementation of learning starting from planning, and second, implementation outside learning, such as routine, spontaneous, and programmed activities, alongside role models by the teachers and environmental conditioning.

Based on the observation results, the following conclusions were made;

1. This character education based on Javanese unggah-ungguh is implemented every day at school.

2. The teachers were role models who gave examples of behavior and speech to students according to the unggah-ungguh.

3. The character education habituation from this culture has shaped students' attitudes and behavior patterns in interacting with teachers, friends, and parents.

Furthermore, based on the observation, the teacher implemented character education of Javanese unggah-ungguh through many areas, including (1) language, which, at certain times, required students to speak soft Javanese (basa krama); (2) attitude, through concrete actions that can be imitated in attitude and body language; (3) Javanese proverb and folk song, which teaches students to understand the philosophy of

41 Shirley Anne S. Paul et al., "Parents' Perspectives on Home-Based Character Education Activities," Journal of Family Studies, 2020, https://doi.org/10.1080/13229400.2020.1806097. 
life from the culture, (4) traditional games, such as Sundamanda, Wong-Wongan, Betengan, etc., which were original Javanese games that taught children to respect their culture; and (5) minimizing the use of gadgets during moments of interaction and socialization.

Ten parents of the $5^{\text {th }}$-grade students were interviewed to reveal their perceptions. Figure 3 shows the results of the survey through these interviews.

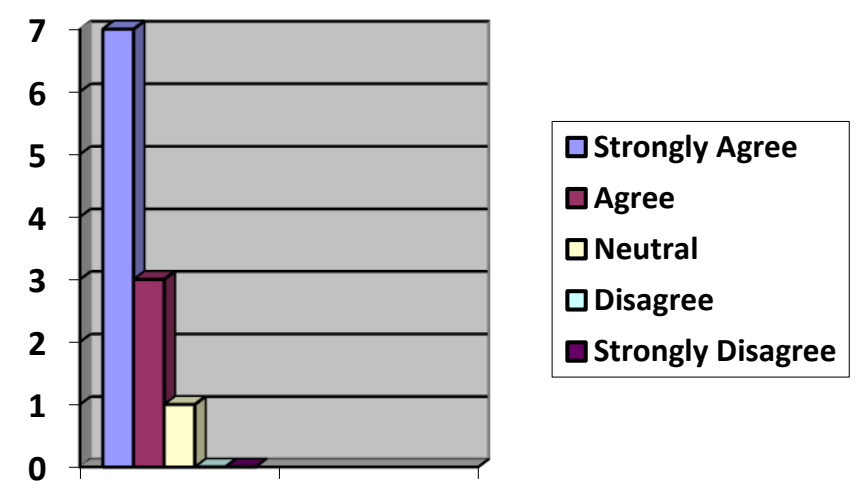

Figure 3

The Result of Survey

From the survey results, character education based on Javanese culture implemented at Madrasah Ibtidaiyah Karanganyar had a positive impact on the development of their children's personalities, according to the parents. The majority reasoned that their children could use soft Javanese (Bahasa krama) while talking to their parents because of the habituation at school. In addition, the children recognized the local culture that was rarely known, such as nembang Jawa, mocopat, and traditional games. According to the parents, getting the children to know traditional games made them less active in accessing gadgets. Another observation that showed the positive perception of parents towards character education was that children become more polite to their parents. The teacher gave several assignment activities to implement character education based on unggah-ungguh to their parents, which the children directly applied at school and home.

An interview was also conducted with the headmaster of Madrasah Ibtidaiyah. He said,

"the implementation of character education based on unggah-ungguh (etiquette) culture is a new policy that aims to preserve Javanese culture, which is increasingly being abandoned by the millennial generation. I want the students not to forget Javanese culture, an ancestral heritage that we must preserve. Soft 
Javanese (Bahasa krama) must be taught to children because it imparts politeness and the rules of speaking to their parents. In addition, this school teaches Javanese cultures such as nembang, mocopat, folklore, and traditional games. Although this is an Islamic school, the content of the Javanese curriculum is still taught, which bestows the school its excellence. Consequently, character education is implemented through daily habits and assignments given by the teachers."

The interview results strengthened the theory of Hildred Geertz, ${ }^{42}$ which stated that two rules must be applied to develop the Javanese culture character, namely behaving politely and respecting others according to degree and position. Based on this theory, the application of character education at Madrasah Ibtidaiyah Karanganyar follows the phase of introducing Javanese culture essentially through attitudes and language. The observations, surveys, and interviews showed this school's success in introducing Javanese culture to the alpha generation at Madrasah Ibtidaiyah Karanganyar. These findings also support several theories, which state that character education is a habit that must be carried out daily to ensure those characters can be embedded in students until adulthood. ${ }^{43}$

In addition, Taxonomy Krathwohl revealed that character education based on Javanese unggah-ungguh (etiquette) culture in Madrasah Ibtidaiyah Karanganyar had reached three levels. Figure 4 shows the result of Taxonomy Krtahwohl

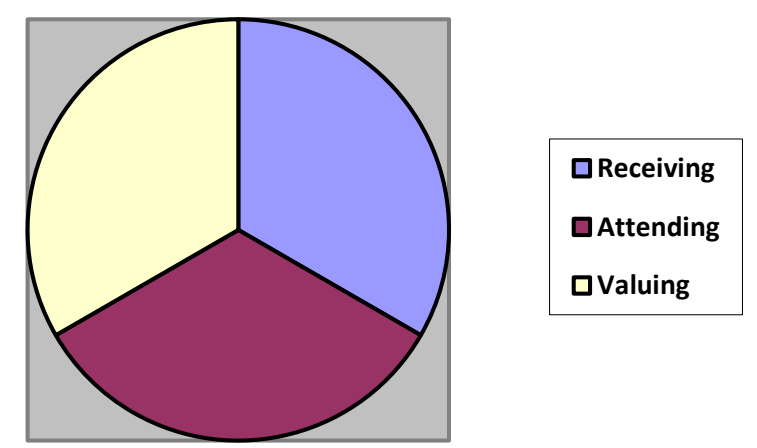

Figure 4

The result of Taxonomy Krathwohl

${ }^{42}$ Hildred Geertz, The Javanese Family: A Study of Kinship and Socialization (New York: Free Press of Glencoe, 1961), https://ehrafworldcultures.yale.edu/document?id=oe05-020.

${ }^{43}$ Michalinos Zembylas, "Transforming Habits of Inattention to Structural Racial Injustice in Educational Settings: A Pedagogical Framework That Pays Attention to the Affective Politics of Habit," Emotion, Space and Society 40 (August 1, 2021): 100817, https://doi.org/10.1016/j.emospa.2021.100817; Wohabie Birhan et al., "Exploring the Context of Teaching Character Education to Children in Preprimary and Primary Schools," Social Sciences \& Humanities Open 4, no. 1 (January 1, 2021): 100171, https://doi.org/10.1016/j.ssaho.2021.100171. 
Three levels in this research, according to Taxonomy Krathwohl, were receiving or attending, responding, and valuing. Students can differentiate, accept, listen, and respond to the six indicators of Javanese unggah-ungguh (etiquette) culture at the receiving or attending level. These are tata krama (manners), lembah manah (relent), andhap asor (humility), tepa slira (tolerance), grapyak (friendliness), and ewuh-pekewuh (reluctance). The students can behave, imitate, and follow the teacher in performing well in the responding level, especially related to the unggah-ungguh (etiquette) culture. Furthermore, at valuing level, the students are willing to accept six indicators as values implemented in their daily life through language and behavior in interacting with others.

\section{CONCLUSION}

The character education based on local wisdom such as Javanese unggahungguh is considered important in this new era. It can be seen from existing phenomena, especially for the alpha generation, as the noble values of etiquette and manners seem to fade away to be replaced by foreign cultures, which are not Indonesian. Therefore, introducing character education based on unggah-ungguh, especially to welcome the alpha generation who live in this digital era, is necessary.

Although unggah-ungguh is originated from Java, it strongly represents the culture of Indonesian society. During the practice of this culture, the students are taught many things, especially about respect, and the focus is not only on attitude but also language. By teaching character education, the students are asked to preserve Javanese unggah-ungguh characters as Indonesian cultural heritage. Consequently, this study shows that character education based on Javanese unggah-ungguh (etiquette) culture in $5^{\text {th }}$-grade students of MI Karanganyar has been performed well. Through this character education, students can receive three levels of the affective domain, namely receiving or attending, responding, and valuing levels, to shape a better personality for them as the alpha generation.

This research was conducted directly in the learning process at Madrasah Ibtidaiyah Karanganyar before the Covid-19 pandemic. Therefore, this study has limitations, namely the impact of Javanese unggah-ungguh (etiquette) culture on children's daily behavior during online school was not analyzed. Hence, further research 
should examine the continuity of character education after children do not go to school offline due to the pandemic.

\section{ACKNOWLEDGMENTS}

The authors want to deliver gratitude to everyone who engages in this research. Moreover, the authors also want to thank all the colleagues in the Teacher Training and Education Faculty, State Institute of Islamic Studies (IAIN) Salatiga, for their kindness and support.

\section{DECLARATION OF CONFLICTING INTERESTS}

The author/s declared no potential conflicts of interest with respect to the research, authorship, and/or publication of this article.

\section{FUNDING}

The authors received no financial support for the research, authorship, and/or publication of this article.

\section{ORCID iD}

Aprilian Ria Adisti (iD) https://orcid.org/0000-0001-5701-1294

Muhamad Rozikan (iD https://orcid.org/0000-0001-6891-9740

\section{REFERENCES}

Adisti, Aprilian Ria. "Internalization Of Javanese Unggah-Ungguh (Etiquette) Character In Modern Era Through Personality Course At English Education Department." AL-ISHLAH: Jurnal Pendidikan 10, no. 2 (December 30, 2018): 216-30. https://doi.org/10.35445/alishlah.v10i2.89.

Aliyah, Istijabatul. "The Roles of Traditional Markets as the Main Component of Javanese Culture Urban Space (Case Study: The City of Surakarta, Indonesia)." IAFOR Journal of Sustainability, Energy \& the Environment, 2016. https://doi.org/10.22492/ijsee.3.1.06.

Arbués, Elena, and Yeni Alicia Servin. "From Global to Local in Character Education. The Case of Paraguay." Estudios Sobre Educacion, 2019. https://doi.org/10.15581/004.37.159-178.

Al Muhdhar, Mimien Henie Irawati, Fatchur Rohman, M Nasir Tamalene, Wawan S Nadra, Alfian Daud, and Hudan Irsyadi. "Local Wisdom-Based Conservation Ethics Of Tabaru Traditional Community On Halmahera Island, Indonesia." International Journal of Conservation Science 10, no. 3 (2019). http://ijcs.ro/public/IJCS-19-49_Almudhar.pdf. 
Balakrishnan, Sai, and Ann Forsyth. "Qualitative Methods." In The Routledge Handbook of International Planning 2019. https://doi.org/10.4324/9781315661063-13.

Banks, James A. "Multicultural Education.” In International Encyclopedia of the Social \& Behavioral Sciences: Second Edition, 2015. https://doi.org/10.1016/B978-008-097086-8.92097-X.

Bates, Agnieszka. "Character Education and the 'Priority of Recognition." Cambridge Journal of Education, 2019. https://doi.org/10.1080/0305764X.2019.1590529.

Bennett, Scott, David R. Gallagher, Graham Harman, Geoffrey J. Warren, and Lihui xi. "Alpha Generation in Portfolio Management: Long-Run Australian Equity Fund Evidence." Australian Journal of Management, 2016. https://doi.org/10.1177/0312896214539815.

Birhan, Wohabie, Gebeyehu Shiferaw, Alem Amsalu, Molalign Tamiru, and Haregewoin Tiruye. "Exploring the Context of Teaching Character Education to Children in Preprimary and Primary Schools." Social Sciences \& Humanities Open 4, no. 1 (January 1, 2021): 100171. https://doi.org/10.1016/j.ssaho.2021.100171.

Bremer, Jozef. "Wittgenstein's Remarks Concerning the Accessibility of Foreign Cultures." Wittgenstein-Studien, 2017. https://doi.org/10.1515/witt-2017-007.

Dewi, Ika Nurani, Sri Poedjiastoeti, and Binar Kurnia Prahani. "ELSII Learning Model Based Local Wisdom To Improve Students' Problem Solving Skills And Scientific Communication." International Journal of Education and Research 5, no. 1 (2017): 107-18. http://br.ijern.com/journal/2017/January-2017/09.pdf.

Fischer, Jean Paul. "Character Reversal in Children: The Prominent Role of Writing Direction." Reading and Writing, 2017. https://doi.org/10.1007/s11145-0169688-y.

Fourtané, Susan. "Generation Alpha: The Children of the Millennial." Interesting Engineering, December 18, 2018. https://interestingengineering.com/generationalpha-the-children-of-the-millennial.

Geertz, Hildred. The Javanese Family: A Study of Kinship and Socialization. New York: Free Press of Glencoe, 1961. https://ehrafworldcultures.yale.edu/document?id=oe05-020.

Gerring, John. "Qualitative Methods." Annual Review of Political Science, 2017. https://doi.org/10.1146/annurev-polisci-092415-024158.

Gill, Sara L. "Qualitative Sampling Methods." Journal of Human Lactation, 2020. https://doi.org/10.1177/0890334420949218.

Halgren, Milan, István Ulbert, Hélène Bastuji, Dániel Fabó, Lorand Eross, Marc Rey, Orrin Devinsky, et al. "The Generation and Propagation of the Human Alpha Rhythm." Proceedings of the National Academy of Sciences of the United States of America, 2019. https://doi.org/10.1073/pnas.1913092116.

Karácsony, Peter, Tilla Izsák, and László Vasa. "Attitudes of z Generation to Job Searching through Social Media." Economics and Sociology, 2020. https://doi.org/10.14254/2071-789X.2020/13-4/14. 
Krathwohl, David R. “A Revision of Bloom's Taxonomy: An Overview." Theory Into Practice 41, no. 4 (November 1, 2002): 212-18. https://doi.org/10.1207/s15430421tip4104_2.

Lavy, Shiri, and Maya Benish-Weisman. "Character Strengths as 'Values in Action': Linking Character Strengths With Values Theory - An Exploratory Study of the Case of Gratitude and Self-Transcendence." Frontiers in Psychology, 2021. https://doi.org/10.3389/fpsyg.2021.576189.

Matta, Corrado. "Qualitative Research Methods and Evidential Reasoning." Philosophy of the Social Sciences, 2019. https://doi.org/10.1177/0048393119862858.

McGrath, Robert E., Hyemin Han, Mitch Brown, and Peter Meindl. "What Does Character Education Mean to Character Education Experts? A Prototype Analysis of Expert Opinions." Journal of Moral Education, 2021. https://doi.org/10.1080/03057240.2020.1862073.

Nagy, Ádám, and Attila Kölcsey. "Generation Alpha: Marketing or Science." Acta Technologica Dubnicae, 2017. https://doi.org/10.1515/atd-2017-0007.

Nixon, Michael, Steve DiPaola, and Ulysses Bernardet. "An Eye Gaze Model for Controlling the Display of Social Status in Believable Virtual Humans." In IEEE Conference on Computatonal Intelligence and Games, CIG, 2018. https://doi.org/10.1109/CIG.2018.8490373.

Paul, Shirley Anne S., Peter Hart, Limor Augustin, Paula J. Clarke, and Mark Pike. "Parents' Perspectives on Home-Based Character Education Activities." Journal of Family Studies, 2020. https://doi.org/10.1080/13229400.2020.1806097.

Peterson, Andrew. "Character Education, the Individual and the Political." Journal of Moral Education, 2020. https://doi.org/10.1080/03057240.2019.1653270.

Purwadi. "Keselarasan Antara Nilai Islam Dan Budaya Jawa Menurut Mangkunegara IV." Ibda' Jurnal Kebudayaan Islam 8, no. 2 (2010): 1-19. https://123dok.com/document/y49g06vz-keselarasan-antara-nilai-islam-danbudaya-jawa.html.

Reis, Thompson Augusto dos. "Study On The Alpha Generation And The Reflections Of Its Behavior In The Organizational Environment." Quest Journals J Res Humanit Soc Sci 6 (2018): 9-19. http://www.questjournals.org/jrhss/papers/vol6issue1/C610919.pdf.

Roller, Margaret R. “A Quality Approach to Qualitative Content Analysis: Similarities and Differences Compared to Other Qualitative Methods." Forum Qualitative Sozialforschung, 2019. https://doi.org/10.17169/fqs-20.3.3385.

Safari, Mohammad, and Dennis Ossy January. "The Development of Virtual Javanese Gamelan to Improve Gamelan Learning Achievement." MUDARRISA: Jurnal Kajian Pendidikan Islam, 2019. https://doi.org/10.18326/mdr.v10i2.222-244.

Sahertian, Pieter, and Umiati Jawas. "Local Wisdom and Excellent Leadership: A Phenomenological Approach." Journal of Advanced Research in Dynamical and Control Systems, 2020. https://doi.org/10.5373/JARDCS/V12SP1/20201139.

Setiawan, Joko Ansari, Suparno, Chuduriah Sahabuddin, Tasrif, and Syahrul Ramadhan. "The Role of Parents on the Character Education of Kindergarten Children Aged 
5-6 Years in Bima." Universal Journal of Educational Research, 2020. https://doi.org/10.13189/ujer.2020.080307.

Shahroom, Aida Aryani, and Norhayati Hussin. "Industrial Revolution 4.0 and Education." International Journal of Academic Research in Business and Social Sciences, 2018. https://doi.org/10.6007/ijarbss/v8-i9/4593.

Singh, Balraj. "Character Education in the 21 st Century." Journal of Social Studies (JSS), 2019. https://doi.org/10.21831/jss.v15i1.25226.

Smith, Sue E., Jon C. Mason, and Majella Bowden. "Local Wisdom in Regenerative Teacher Practices." Australian Journal of Teacher Education, 2020. https://doi.org/10.14221/ajte.2020v45n9.6.

Sukadari, Moh. Buchory, Sukemi, and Sunarti. "Local Socio-Cultural Wisdom as a Basis of Character Education in Primary Schools." International Journal of Innovation, Creativity and Change 7, no. 6 (2019): 298-311. https://www.ijicc.net/images/vol7iss6/7620_Sukadari_2019_E_R.pdf.

Supartinah, Supartinah, Sekar Purbarini Kawuryan, and Woro Sri Hastuti. "Javanese Graded Reading Books For Elementary School Students.” RETORIKA: Jurnal Bahasa, Sastra, Dan Pengajarannya 13, no. 1 (February 23, 2020): 56-65. https://doi.org/10.26858/retorika.v13i1.11321.

Suryanto, Tulus. "Cultural Ethics And Consequences In Whistle-Blowing Among Professional Accountants: An Empirical Analysis." Journal of Applied Economic Sciences $12, \quad$ no. 617 (2017). http://cesmaa.org/Docs/JAES\%20Fall\%206(52)2017_online.pdf\#page=70.

Susilo, Sulistiyono, and Ibnu Syato. "Common Identity Framework of Cultural Knowledge and Practices of Javanese Islam.” Indonesian Journal of Islam and Muslim Societies, 2016. https://doi.org/10.18326/ijims.v6i2.161-184.

Susylowati, Eka. "The Use of Javanese by Society of Keraton Surakarta Hadiningrat." Journal of English Teaching and Learning Issues, 2019. https://doi.org/10.21043/jetli.v2i1.5227.

Varvin, Sverre. "“The Essay Method' a Qualitative Method for Studying Therapeutic Dialogues." Scandinavian Psychoanalytic Review, 2019. https://doi.org/10.1080/01062301.2019.1692622.

Weststrate, Nic M., Michel Ferrari, and Monika Ardelt. "The Many Faces of Wisdom: An Investigation of Cultural-Historical Wisdom Exemplars Reveals Practical, Philosophical, and Benevolent Prototypes." Personality and Social Psychology Bulletin, 2016. https://doi.org/10.1177/0146167216638075.

Wilson, Leslie Owen. “Bloom's Taxonomy Revised.” The Second Principle (blog), 2017. https://thesecondprinciple.com/essential-teaching-skills/blooms-taxonomyrevised/.

Zembylas, Michalinos. "Transforming Habits of Inattention to Structural Racial Injustice in Educational Settings: A Pedagogical Framework That Pays Attention to the Affective Politics of Habit.” Emotion, Space and Society 40 (August 1, 2021): 100817. https://doi.org/10.1016/j.emospa.2021.100817. 